\title{
HUBUNGAN ANTARA PENGUASAAN TATA BAHASA DENGAN KETERAMPILAN MENULIS NARASI BAHASA INGGRIS SISWA KELAS XI SMK NEGERI 2 DEPOK
}

\author{
Prita Pantau Putri Santosa \\ Dosen Universitas Indraprasta PGRI Jakarta \\ Program Studi Teknik Industri \\ pritapantau@ymail.com
}

\begin{abstract}
The goal of this research is to analyse and prove the correlation between grammar mastery and students'English narrative writing skill at the 11th grade of SMK Negeri 2 Depok. Research data was collected by giving multiple cohoice tests of grammar and narrative writing skill. Furthermore, the data was analyzed quantitatively in order to know correlation coefficient, determination coefficient and signifinancy coefficient as part of hypothesis test. Data analysis was conducted with $\alpha=0,05$. Based on the result of hypothesis test, the researcher has found the significant correlation of grammar mastery and students' English narrative writing skill.
\end{abstract}

Kata Kunci: Penguasaan Tata Bahasa, Ketrampilan Menulis Narasi

\section{PENDAHULUAN}

\section{LATAR BELAKANG}

Salah satu masalah yang menarik untuk dikaji berkaitan dengan penguasaan bahasa Inggris yang baik adalah mengenai tata bahasa (grammar). Fungsi bahasa yang utama adalah untuk berkomunikasi. Dalam berkomunikasi setiap pembicara tentulah berusaha agar apa yang ada didalam pikirannya dapat tersampaikan dengan baik dan jelas. Ia ingin agar pesannya dapat dipahami dengan baik oleh pendengar. Namun, hal ini seringkali sulit dilakukan, proses penyampaian pesan sering terhambat karena beberapa factor, misalnya adanya gangguan dan keterbatasan kemampuan bahasa (mencakup tata bahasa dan kosakata) yang sering dialami oleh pembelajar bahasa.

Jika ditinjau dari fungsinya, bahasa Inggris merupakan bahasa internasional yang harus dikuasai, terutama dalam masa modern seperti saat ini. Penguasaan bahasa mencakup berbagai kemampuan (skill) diantaranya kemampuan mendengar (listening skill), kemampuan berbicara (speaking skill), kemampuan membaca (reading skill), serta kemampuan menulis (writing skill). Secara praktis, keempat jenis kemampuan tersebut sangat menunjang. Contohnya, kemampuan berbicara dalam berbahasa Inggris akan terasah dengan seiringnya kita mendengar lagulagu dalam bahasa Inggris. Kata-kata yang tidak dimengerti saat kita mendengarkan lagu tersebut menuntut untuk mencari makna kata-kata tersebut didalam kamus. Selanjutnya kata-kata asing tersebut biasanya akan kita ucapkan atau nyanyikan. Saat kata-kata asing tersebut tertulis dalam teks atau bacaan tertentu, pastilah kita telah mengetahui maknanya. Dengan demikian, kita yang sebelumnya hanya ingin mengembangkan kemampuan berbicara, secara simultan akan turut mengembangkan kemampuan mendengar dan membaca. 
Uraian di atas menunjukan bahwa kemampuan menulispun merupakan salah satu kunci penting dalam penguasaan suatu bahasa, khususnya bahasa inggris. Bahasa Inggris tidak sekedar dikomunikasikan secara lisan, namun dapat juga berupa tulisan karena dapat menampung lebih banyak ide dan kesan jika kita mengetahui dan mengaplikasikan teknik menulis yang tepat karena dapat mengasah kemampuan kosakata, tata bahasa, dan pengucapan. Dalam situasi tertentu, contohnya melamar pekerjaan, kita diharapkan mampu menulis kualifikasi diri dalam bahasa Inggris. Selain itu penulisan yang tepat tersebut akan berguna sebagai sarana promosi diri kita pada perusahaan atau pekerjaan yang diinginkan. Situasi lainnya bila berhadapan dengan tes menulis dalam TOEFL dan ujian masuk perguruan tinggi. Kemampuan untuk menerapkan teknik menulis yang baik akan meningkatkan peluang kita untuk mendapatkan hasil yang memuaskan dengan pemanfatan waktu yang efektif.

Keterampilan menulis khususnya dalam bahasa Inggris akan sangat berguna saat kita ingin menuangkan ide kreatif dalam bentuk karya tulis, surat pribadi, puisi, prosa, novel dan lain-lain. Oleh karena itu, kemampuan menulis dalam bahasa Inggris sebenarnya sama pentingnya dengan kemampuan berbicara, bahkan akan lebih jauh lebih tepat sasaran jika kita dapat mengeksplorasi dan memanfaatkannya dengan cerdas. Namun keterampilan menulis tampaknya masih sangat sedikit mendapat perhatian. Harus disadari bahwa keterampilan menulis sangat diperlukan dalam kehidupan modern, tetapi pada kenyataannya masih banyak siswa yang belum menguasai keterampilan menulis.

Dalam konteks penelitian ini, penulis ingin tahu sejauh mana kemampuan siswa dalam keterampilan menulis narasi. Sebenarnya untuk membangun kemampuan menulis peserta didik tidaklah sulit. Hal tersulit adalah untuk memulai menulis. Ketika menulis sudah dimulai, maka akan terlihatlah kemampuan mereka dalam berkreativitas dan berimajinasi. Setelah mereka mulai terbiasa untuk menulis, guru juga hendaknya mengimbangi dengan penguasaan tata bahasa Inggris yang baik. Mungkin siswa bisa menulis dalam bahsa Inggris tanpa penguasaan tata Inggris yang baik, tetapi sudah bisa dipastikan bahwa struktur kalimatnya kurang bagus.

Hal ini dapat membuat penerima pesan komunikasi tulisannya kurang memahami maksudnya. Dengan kata lain, penguasaan tata bahasa Inggris yang baik akan membuat siswa mampu berkomunikasi baik secara lisan maupun tulisan dengan benar, lancar dan elegan. Artinya siswa dapat belajar bahwa suatu kalimat disusun dari suatu struktur dan bukan struktur yang lain. Dari pengamatan terhadap kalimat, siswa dapat menggali lebih dalam apa yang ada dalam kalimat dan yang tidak ada dalam kalimat agar mampu berkomunikasi dalam bahsa Inggris, baik secara lisan maupun secara tertulis dengan baik dan benar.

Mengacu pada keseluruhan paparan diatas dan dalam upaya memahami serta memecahkan masalah keterampilan menulis siswa yang belum optimal, maka penulis berminat untuk mengadakan penelitian dengan judul "Pengaruh penguasaan tata bahasa terhadap keterampilan menulis narasi bahasa Inggris siswa kelas XI Sekolah Menengah Kejuruan Negeri 2 Depok".

\section{IDENTIFIKASI MASALAH}

Berdasarkan uraian permasalah-an di atas, maka masalah dalam penelitian ini diidentifikasikan sebagai berikut. 
1. Bagaimana keterampilan menulis narasi bahasa Inggris siswa kelas XI Sekolah Menengah Kejuruan Negeri 2 Depok?

2. Bagaimana penguasaan tata bahasa Inggris siswa kelas XI Sekolah Menengah Kejuruan Negeri 2 Depok?

3. Bagaimana meningkatkan hasil belajar tata bahasa Inggris kelas XI Sekolah Menengah Kejuruan Negeri 2 Depok?

4. Apakah media menulis narasi dapat meningkatkan penguasaan tata bahasa siswa kelas XI Sekolah Menengah Kejuruan Negeri 2 Depok?

5. Apakah penguasaan tata bahasa (grammar) Inggris mempengaruhi keterampilan menulis narasi bahasa Inggris siswa kelas XI Sekolah Menengah Kejuruan Negeri 2 Depok.

\section{RUMUSAN MASALAH}

Berdasarkan pernyataan pembatasan masalah di atas, masalah dalam penelitian ini secara spesifik dirumuskan dalam pertanyaan penelitian sebagai berikut ;

1. Apakah ada pengaruh penguasaan tata bahasa terhadap keterampilan menulis narasi bahasa Inggris siswa kelas XI Sekolah Menengah Kejuruan Negeri 2 Depok?

2. Seberapa besar pengaruh penguasaan tata bahasa Inggris siswa kelas XI Sekolah Menengah Kejuruan Negeri 2 Depok?

\section{KAJIAN TEORI \\ Hakikat Menulis}

Alasan utama dalam pengajaran menulis tentunya bahwa menulis adalah sebuah keahlian dasar dalam bahasa, menulis sama pentingnya dengan berbicara (speaking), mendengarkan (listening), dan membaca (reading).
Siswa harus tahu bagaimana cara menulis surat, menulis sebuah laporan, cara menulis iklan, dan cara menulis dengan mengguanakan media elektronik maupun yang lainnya. Mereka harus mengetahui beberapa kaidah dalam menulis (Mansyur, 2008:3)

Pada umumnya guru akan selalu mencoba mendapatkan siswa menulis sejumlah gaya dalam keadaan biasa setiap hari, seperti memasukan kartu pos, macam-macam jenis tulisan, pengisian dalam bentuk lamaran kerja, menulis komposisi naratif, laporan artikel, surat kabar, majalah dan lain-lain. Guru juga mengajarkan siswa tentang kaidah penulisan, teks dialog, bermain drama, iklan, puisi dan semacamnya karena jika guru melakukan hal ini akan berdampak positif untuk memberikan dorongan atau motifasi kepada siswa agar lebih kreatif (Nurholis, 2008:5).

Tentang paradigma penelitian, Wishon (1980:20) menyatakan sebagai berikut :

"Assumers that students have completed a basic course (350400) or its equivalent and have considerable experience in the reading the language. it is the stage of competence in our opinion, that students can most profitable take up the task of learning to write English"

Beberapa poin penting dari pembahasan yang ada dalam menulis sebagaimana disebutkan, bahwa setiap tulisan dalam konteks tertentu memiliki format tersendiri. Seorang penulis bijaksana akan dengan segera mengumpulkan model-model atau contoh-contoh tulisan dalam berbagai konteks dan jenis. Ini bukan untuk kepentingan penjiblakan, karena penjiplakan merupakan salah satuu dosa besar dalam dunia menulis. Memiliki atau meyiapkan model dan format tulisan untuk konteks tertentu 
merupakan sandaran bagi penulis untuk menulis dan demi diterimanya tulisan tersebut sebagai sebuah tulisan yang layak.

\section{Ketrampilan Menulis}

Keterampilan menulis merupakan salah satu keterampilan berbahasa yang yang paling tinggi tingkatannya. Menulis adalah suatu proses penuangan ide atau gagan dalam bentuk paparan bahasa tulis berupa rangkaian simbolsimbol bahasa (Baradja, 1975:42).

Zainurrahman (2011:68) menemukan bahwa "Keterampilan bahasa dibagi dua jenis, yaitu keterampilan yang hanya bisa diperoleh melalui latihan-latihan dan penguasaan konsep tertentu". Dapat dimaksudkan bahwa keterampilan menulis dan membaca hanya bisa diperoleh melalui latihan-latihan yang ketat dengan penguasaan konsep-konsep tertentu, dapat dimaklumi mengapa tidak semua orang dapat menulis dan membaca dengan baik.

Bahwa melatih diri menulis dan menguasai keterampilan menulis turut menjamin keterampilan membaca, hal ini menjadi logis ketika seseorang memahami teks bacaan. Artinya, orang yang bisa menulis dengan baik memiliki kemampuan untuk memahami tulisan orang lain secara lebih kritis.

"This mean that when you first write something down you have already been thinking about what you are going to say and how you are going to say it. Then you have finished writing, you read over what you written and ake changes and corrections. There fore, writing is never a one step action it is a process has several steps" (Oshima dan Hongue, 2003:135).

Oleh karena itu menulis bukan hanya satu langkah kegiatan tetapi membutuhkan beberapa langkah kegiatan. Oshima juga menyatakan bahwa "Prewriting is the first step in the writing process. In the step, you gather idea to write about. One way to gather ideas is to discuss a topic with your classmates and take notes" (Oshima dan Hongue, 2003:135). Pada langkah pertama dalam proses menulis adalah mengumpulkan gagasan-gagasan itu kemudian berdiskusilah dengan teman sekelas lalu buat catatan-catatan apa yang akan ditulis.

Dalam proses menulis sebaiknya penulis harus mengingat bukan hanya tanda symbol atau tanda grafik tetapi juga isi pesan dalam teks atau cerita, maksud dan tujuan bagi pembaca. Tetapi itu saja tidaklah cukup karena penulis juga harus merealisasikan tulisan dengan topik yang penulis buat. Penulisan pada waktu yang berbeda akan menciptakan bentu-bentuk tulisan yang berbeda serta memunculkan hal-hal baru yang menarik untuk ditulis dan dibaca oleh khlayak ramai.

Syamsudin (1994:31) menemukan bahwa "Menulis adalah aktivitas seseorang dalam menuangkan ideidepikiran dan perasaan secara logis dan sistematis dala bentuk tertulis. Sehingga pesan melalui tulisan tersebut dapat dipahai oleh pambaca".

Tentang keterampilan menulis, Tarigan (1989:15) menyatakan sebagai berikut:

Menulis merupakan suatu keterampilan berbahasa yang digunakan untuk berkomunikasi secara tidak langsung (tidak secara tatap muka dengan lawan bicara). Menulis juga merupakan suatu kegiatan yang produktif dan ekspresif karena dalam kegiatannya penulis harus dituntut terampil dalam memanfaatkan struktur tata bahasa dan pemilhan kosakata yang tepat karena keterampilan menulis tidak datang secara otomatis elainkan harus 
melalui latihan dan praktek yang terus menerus secara teratur

Kemampuan menulis adalah salah satu unsur kognitif yang menekankan ingatan dan daya ingat. Siswa dapat berpikir jika meraka dapat mengingat beberapa informasi tentang ingatan itu. Menulis terkandung dalam area kognitif dapat juga dikatakan bahwa kemampuan menulis mepunyai aturan yang penting dalam pembentukan tulisan karena menulis tidak boleh terjadi dala sebuah situasi atau kondisi kosong.

Galko (1992:276) menemukan bahwa "Dalam proses menulis, penulis harus berfikir bahwa dia sudah pasti menciptakan lebih dari satu tulisan". Dalam artian bahwa penulisan pertama hanyalah sebuahlangkah awal elaborasi ide, dan setelah penulisan pertama maka tulisan tersebut perlu kembali ditata ulang, diperiksa, dan diperbaiki, atau direvisi.

Salah satu pakar berpendapat "Thinking can not be carried in a vacuum, but must be based upon knowledge of some realities" Bloom (1956:33). Intinya adalah tidak ada yang dibawa dalam sebuah kekosongan, tetapi harus didasarkan pada beberapa pengetahuan nyata.

Doilite (1985:4) mengungkapkan tentang "Writing as thinking process, at least involve three factors : something to say, someone to say, and the skill of how to say it". Dari pendapatnya bahwa menulis sebagian dari proses berpikir, paling sedikit mengandung tiga sebab: sesuatu yang dikatakan, seseorang yang mengatakan dan keterampilan bagaimana mengatakannya. Dijelaskan pula aturan-aturan sadar yang dikumpulkan dalam Writer's Long Term Memory (LTM) tentang aturan-aturan yang diaplikasikan dalam proses menulis.

Nold (1981:70) menemukan bahwa "In writing process, plnning, translating, reviewing, skill of syntax, vocabulary, orthographies, and convention must be taken into account". Maksudnya adalah dalam proses menulis dalam merencanakan, menerjemahkan, meninjau kembali, keahlian tangan, dan keahlian tertentu seua itu harus ditikberatkan ataupun dilibatkan kedalam proses tersebut.

Garis besarnya adalah keterampilan menulis sangat penting didalam proses menulis karena keterampilan tersebut mengandung keahlian struktur, kelompok kata, cirriciri atau sifat kata, dan perumusan topik. Akhirnya keterampilan bahasa mengandung urutan atau susunan menulis, kosakata dan penggunaan tata bahasa. Dengan kata lain keterampilan menulis bukan hanya kemampuan bahasa tetapi juga pusat dalam proses menulis yang membutuhkan keahlian atau penguasaan komponen-komponen yang dibutuhkan untuk menulis.

Tarigan (1987:21) mengungkapkan tujuan dalam menulis adalah memberitahukan atau mengajar, meyakinkan atau mendesak, menghibur atau menyenangkan, dan mengutarakan perasaan dan emosi yang berapi-api.

Billow dalam Pateda (1987) menyebutkan tipe-tipe tulisan sebagai berikut : 1) Laporan, yakni biasanya tulisan yang berisi fakta yang berhasil dikumpulkan dilapangan. 2) Timbangan, yaitu menulis isi buku berkaitan dengan ide yang dikemukakan penulis, hal-hal yang disetujui dan yang ditolak. 3) Iklan, yaitu tulisan yang berupa penawaran promosi. 4) Artikel, yaitu tulisan ilmiah yang membicarakan masalah aktual. 5) Surat

Hal ini didukung oleh pendapat (Mohan, 1960:6) merumuskan ciri-ciri tulisan yang baik adalah sebagai berikut: 1) Jujur; jangan coba memalsukan gagasan atau ide, 2) Jelas; jangan membingungkan para pembaca, 3) Singkat; 
jangan memboroskan waktu para pembaca, 4) Usahakan keanekaragaman; panjang kalimat yang beraneka ragam; berkarya dengan penuh kegembiraan.

Terkaitan dengan penulisan, Ur (1996:163) menyatakan sebagai berikut :

"The purpose of writing in principle is the expression of ideas the conveying of $m$ essage to the reading;so the ideas themselves should arguably be seen as the most important aspect of writing". Tujuan dalam prinsip menulis adalah mengungkapkan ide-ide, menyampaikan sebuah pesan ke pembaca, sehingga ide-ide mereka sendiri akan dikritik dan dilihat sebagai aspek menulis yang paling penting. Dengan kata lain menulis juga membutuhkan perhatian untuk aspek-aspek formal, tulisan tangan yang rapi, pengucapan tanda baca yang benar, sama baiknya dengan tata bahasa (grammar) yang tepat dan menyeleksi kosa kata (vocabulary) dengan teliti. Hal ini dikarenakan banyaknya standar bahasa yang lebih tinggi secara normal bergantung dalam menulis dari pada berbicara.

Saat ini salah satu masalah dalam pengajaran keterampilan menulis adalah memelihara sebuah keseimbangan antara isi dan bentuk kata ketika mendefinisikan keperluan dan penafsiran kita. Keseimbangan yang baik ini tergantung pada guru yang memberikan arahan pengajaran dan pendapat tentang begitu banyak maanfaat yang akan didapat jika siswa gemar menulis narasi.

\section{Pengertian Narasi}

Tulisan narasi memiliki empat elemen wajib dan satu elemen opsional. Keempat elemen wajjib antara lain orientasi, komplikasi, evaluasi, dan resolusi. Sementara satu elemen opsional adalah koda (Andeson, 1997:8 ; Evans, 2000; Alwasilah, 2005; Feez dan Joyce, 2003). Setiap elemen memiliki fungsi yang berbeda dan secara umun struktur skematik kelima unsur tersebut diatur sebagaimana urutan-urutan yang ada di atas. Akan tetapi tidak selamanya demikian, struktur skematiknya sangat tergantung pada tujuan atau selera penulis.

Narasi juga merupakan salah satu jenis pengembangan paragrap dalam sebuah tulisan yang rangkaian peristiwa dari waktu ke waktu dijabarkan dengan urutan awal, tengah, dan akhir.

Ciri-ciri karangan narasi : 1) Menonjolkan unsur perbuatan atau tindakan, 2) Dirangkai dalam urutan waktu, 3) Berusaha menjawab pertanyaan "apa yang terjadi?", 4) Ada konfliks. Keraf (2000:136).

Antar (2003:31) menemukan bahwa:

"Narasi dibangun oleh sebuah alur cerita. Alur ini tidak akan menarik jika tidak ada konfliks. Cirri-ciri narasi diantaranya berupa cerita tentang suatu pristiwa, kejadiannya dapat berupa kisah nyata, imajinasi ataupun keduanya, dan yang paling penting memiliki konfliks serta menekankan susunan secara kronologis".

Ciri yang dikemukakan Keraf memiliki persamaan dengan Antar Semi, bahwa narasi berisi ciri suatu cerita, menekankan susunan kronologis atau dari waktu ke waktu dan memiliki konfliks. Perbedaannya, Keraf lebih memilih cirri yang menonjolkan pelaku.

Tujuan menulis karangan narasi secara fundamental (Zainurrahman, 2011:38) menyatakan hendaknya memberikan informasi atau wawasan dan memperluas pengetahuan serta 
memberikan pengalaman estetis kepada pembaca.

\section{Keterampilan Menulis Narasi}

Keterampilan berbahasa juga dapat dikatagorikan dari aspek pemerolehannya, yakni pemerolehan alami dan pemerolehan tidak alami. Berbicara dan mendengar sudah merupakan hakekat dasar manusia, sehingga pemerolehan dua keterampilan tersebut bisa didapati melalui interaksi alamiah dengan masyarakat pengguna bahasa sekitar dan latihan-latihan tertentu yang didukung oleh lingkungan yang sifatnya alamiah (Tarigan. 2008) juga menambahakan bahwa, berbeda dengan keterampilan menulis dan membaca, setiap manusia hanya bisa memperoleh dan mengembangkan keterampilan tersebut dengan menguasai konsep-konsep teoritis tertentu, disertai dengan latihan- latihan yang sudah pasti "jatuh-bangun" dalam mencapai penguasaan keterampilan tersebut.

Menulis memerlukan beberapa kemampuan yang harus dimiliki seseorang untuk menghasilkan tulisan yang baik. Hal ini dinyatakan oleh Suhendar dan Supinah (1992:5) yaitu :

Isi karangan merupakan gagasan / ide karangan yang dituangkan dalam keseluruhan karangan, pengembangan pola-pola kalimat sesuai dengan struktur kebahasaan yang berlaku, artinya apakah urutan kalimat pada suatu paragrap sudah kohesi dan kohernsi, memilih istilah dan kosakata yang tepat sesuai dengan gagasan yang disampaikan, menggunakan ejaan yang sesuai dengan peraturan ejaan yang berlaku. Ketepatan ejaan meliputi; cara penulisan huruf, cara penulisan kata, cara penulisan unsur serapan, dan pemakaian tanda baca.

Selain apa yang di sebutkan Suhendar dan Sapinah dalam menulis tidak dapat diabaikan faktor kelogisan dan kesistematisan. Jika semua sudah terpenuhi oleh seorang penulis, akan menghasilkan suatu tulisan yang memiliki norma/kaidah kebahasaan sehingga memperlihatkan hubungan yang logis dan sistematis.

Keterampilan menulis tidak hanya mempelajari tata bahasa dan pengetahuan tentang tulis-menulis secara teratur dan terarah. Hal ini sesuai dengan pendapat Tarigan (1983:4) menyatakan bahwa "Keterampilan menulis tidak akan datang secara otomatis, melainkan harus melalui latihan dan praktek yang banyak dan teratur".

Keterampilan menulis tidak dapat dipisahkan dari kemampuan berpikir seseorang, karena berpikir itu adalah suatu proses mental dalam menentukan suatu ide pikiran serta gagasan-gagasan. Dari bahasa seseorang akan mencerminkan pikirannya. Jadi untuk mendapatkan keterampilan menulis yang baik harus diperlukan latihan yang terarah serta latihan bagaimana cara berpikir dengan baik ( Chaer, 1993:128).

Proses kemampuuan menulis naarasi akan melibatkan kemampuan penalaran. Maka kegiatan menulis narasi dapat dikatakan sebagai proses penalaran. (Sabarti dkk, 1990:3) mengemukakan "Proses kemampuan menulis itu meliputi tiga tahap penulisan yang terdiri dari tahap pra-penulisan, tahap penulisan, dan tahap revisi”.

Keterampilan menulis sangat penting bagi setiap siswa karena banyak tugas dan kewajiban dituangkan kedalam tulisan. Sejak kanak-kanak hingga perguruan tinggi dalam hal menulis masih banyak yang mengalami kesulitan. Dalam proses mengajar di 
kelas sebaiknya guru harus sering memberikan latihan-latihan dengan memberikan contoh tulisan orang lain ataupun artikel-artikel dan tidak hanya menerangkan teori-teori dalam menulis (Alwasilah, 2011:185).

Keterampilan menulis narasi harus memiliki berbagai penguasaan, misalnya penguasaan aspek kebahasaan dan aspek diluar bahasa. Aspek kebahasaan meliputi ejaan, tanda baca, huruf capital, dan tata bahasa. Sedangkan aspek diluar bahasa adalah kemampuan mengembangkan gagasan serta kerapihan tulisan. Baik aspek bahasa maupun aspek luar bahasa harus dijalani sedemikian rupa sehingga menghasilkan tulisan narasi yang baik (Alwasilah, 2011:185).

Dapat disimpulkan bahwa keterampilan menulis narasi adalah tindakan seseorang dalam mengungkapkan gagasan, pemikiran, pengetahuan, dan ilmu yang dimilki yang dilakukan secara terus menerus dan teratur dalam bentuk narasi.

\section{Hakekat Tata Bahasa}

Untuk menciptakan sebuah tulisan yang layak dibaca, ada tiga hal yang perlu dipertimbangkan, Manser (2006) meyatakan sebagai berikut:

"Apa yang anda tulis hendaknya benar secara tata bahasa (grammatically correct) dan sesuai dengan penggunaan bahasa yang lazim. Tata bahasa adalah norma-norma bahasa yang dianut oleh sekelompok penutur atau pengguna bahasa tertentu. Tata bahasa bukanlah sebuah sains esoteric, namun merupakan kaidah penggunaan bahasa onvensional. Kesalahan dalam tata bahasa menyebabkan ketidak jelasan. Yang kedua adalah penempatan kosakata dan konstruksi kalimat seyogianya digunakan sesederhana mungkin tanpa mendistorsi makna yang ingin disampaikan. Yang terakhir penggunaan sinonim yang cocok dan relevan, kontekstual dan umum. Meskipun sekali-kali kita bisa menggunakan sinonim yang lebih indah dan langka digunakan, namun masih tetap relevan dengan konteks dan jenis tulisan yang sedang kita tulis".

Burke (2007:5) berpendapat bahwa "Tata bahasa inggris merupakan salah satu bagian terpenting yang harus dikuasai oleh seseorang pada saat pertama kali mempelajari bahasa Inggris, baik itu secara lisan maupun secara tulisan".

Hal ini berarti mereka lebih menekankan kepada kita bahwa : untuk bisa belajar menguasai bahasa Inggris, kita harus lebih memperhatikan tata bahasa, karena hal itu merupakan bagian terpenting dalam berbahasa Inggris yang berfungsi mengatur pola pembentukan bahasa Inggris serta penggunaan bentuk waktu (tenses) yang harus diperhatikan pada saat menyusun sebuah kalimat bahasa Inggris, agar kalimat-kalimat yang akan disampaikan mengandung makna atau arti yang benar (Burke, 2007).

GTM (Grammar Translation Method) merupakan salah satu cara atau menurutnya untuk meningkatkan kemampuan siswa dalam pembelajaran bahasa asing harus disesuaikan dengan bahasa yang mereka pakai dalam kehidupan sehari-hari. Maksudnya agar pembelajaran menjadi efektif dan dimengerti oleh siswa dalam mempelajari bahasa tersebut. Selain itu juga harus diselingi oleh bahasa yang digunakan atau bahasa ibu (mothertongue) sehingga proses dalam belajar dapat tercapai dengan mudah dan dimengerti apa yang dimaksud dalam proses pembelajaran tersebut (Henry 
Sweet dari Inggris, Wilhem Victor dari Jerman, dan Paul Passy dari Frencebegan, 1880).

Seperti kalimat pernyataan baik itu berupa positif atau pun negatif (declarative), contohnya You are not responsible ; I do not agree with your opinion. Kalimat tanya (question), contohnya Does Risman live in Bogor?; Is your sister good at cooking?. Kalimat perintah atau larangan (imperlative), contohnya Get out!; Come on!; Close the door, please!; Don't leave me alone!. Terakhir adalah kalimat yang menyatakan sebuah perasaan yang kuat dan bisa juga menyatakan sebuah doa (exlamative). Dalam membuat exclamatory yang menyatakan perasaan yang kuat bisa memakai what/how yang memiliki arti "sungguh" (bukan apa/bagaimana). Perbedaan pemakaiannya adalah pada kata yang diikutinya. What diikuti oleh noun (kata benda) sedangkan how diikuti oleh adjective (kata sifat). Contoh: What a big house!; How big the house is!; What a smart girl!; How smart the girl is! Contoh untuk yang menyatakan doa: God bless you; Praise be to God.

Agar lebih baik dalam menguasai bahasa Inggris maka para ahli bahasa membuat suatu ide atau metode yang disebut dengan GTM (Grammar Translation Method) dimana metode ini diprakarsai oleh (Henry Sweet dari Inggris, Wilhem Victor dari Jerman, dan Paul Passy dari Frencebegan pada tahun1880). Mereka mendefinisikan GTM (Grammar Translation Method) is a way of studying a language that approaches the language first through detailed analysis of its grammar rules, which consist of morphology and syntax.

Thomson dan Martinet (2012) menjelaskan bahwa untuk belajar tata bahasa ada empat langkah yang harus diperhatikan sebagai berikut : 1)Explanation and example have been brought to explain a topic, 2) Must more information about knowledge use, 3) Some material has been rearranged to make comparison easier, 4) The content list must have summarizes every section.

Bower (2012) mengemukakan bahwa ada empat fungsi jika kita memahami tata bahasa yang baik, di antara adalah untuk mengetahui tingkat kemampuan kesadaran berbahasa dan menggolongkannya kedalam tingkatan baik itu menengah atau lanjutan dari si pembelajar itu sendiri, untuk membangun kemampuan dan penguasaan pembelajaran dalam berkomunikasi menggunakan tata bahasa dengan baik sesuai dengan aturan tata bahasa itu sendiri, memanfaatkan alam sebagai alat pembelajaran berkomunikasi menggunakan tata bahasa (grammar) bahasa inggris itu sendiri, untuk mengetahui bentuk bahasa formal menurut aturan kalimat dalam bahasa Inggris dan mengerti maksud dari kalimat itu sendiri untuk mempermudah dalam mengajar dan belajar tata bahasa (grammar).

Burke (2007:23) menemukan bahwa di dalam tata bahasa Inggris, kata yang digunakan untuk menyusun sebuah kalimat dapat dibedakan menjadi delapan kelompok atau disebut The Eight Part of Speech, di anataranya sebagai berikut : Kata Benda (Noun), Kata Kerja (Verb), Kata Sifat (Adjective), Kata Keterangan (Adverb), Kata Ganti (Pronoun), Kata Depan (Proposition), Kata Sambung (Conjunction), dan Kata Seru (Interjection). Kedelapan kelompok kata ini merupakan bagian terpenting dalam tata bahasa yang harus dipahami dan dimengerti oleh seorang yang ingin belajar bahasa Inggris.

Dari uraian di atas memberikan gambaran bahwa tata bahasa merupakan memiliki variasi dalam struktur dan penggunaannya, itu tergantung tradisi yang digunakan oleh suatu negara yang 
dipengaruhi oleh bahasa asli dari negara tersebut. Secara umum, tata bahasa yang dipedomani adalah tata bahasa Inggris Amerika dan Inggris Britania Raya (British).

\section{KERANGKA BERPIKIR}

Keterampilan menulis penting untuk membuat sebuah teks yang baik, karena meskipun kita memilih pengetahuan topik, bentuk yang tepat dan pertimbangan pembaca, namun jika teks tidak disusun dengan baik maka komunikasi dalam berhubungan akan tidak efektif. Agar siswa dapat menulis bahasa Inggris dengan baik dan benar maka siswa harus mampu menguasai tata bahasa. Karena dengan menguasai tata bahasa akan meningkatkan keterampilan menulis bahasa Inggris siswa.

Berdasarkan hal di atas maka jelaslah bahwa terdapat hubungan yang positif antara penguasaan tata bahasa Inggris dengan keterampilan menulis narasi berbahasa Inggris siswa di sekolah.

\section{Hipotesis}

Berdasarkan latar belakang penelitian dan identifikasi masalah serta kerangka berfikir, maka dalam penelitian ini penulis merumuskan rumusan hipotesis, yaitu pengaruh antara penguasaan tata bahasa dengan kemampuan menulis narasi bahasa Inggris siswa kelas XI SMK Negeri 2 Depok yang dirumuskan sebagai berikut: Hipotesis Nol (Ho): Tidak terdapat pengaruh antara pengaruh ...penguasaan tata bahasa Inggris dengan ...keterampilan menulis narasi Bahasa Inggris ... siswa kelas XI Sekolah Menengah Kejuruan ... Negeri 2 Depok. Hipotesis Penelitian (Hp): Terdapat pengaruh antara penguasaan tata bahasa Inggris dengan keterampilan menulis narasi Bahasa Inggris siswa kelas XI SMK Negeri 2 Depok.

\section{METODE PENELITIAN}

Penelitian ini merupakan penelitian kuantitatif dengan menggunakan metode survey. Dari populai sebanyak 200 siswa kelas XI SMK Negeri 2 hanya 30 siswa yang dijadikan sampel dengan metode random sampling. Sementara itu, instrumen yang digunakan sebagai alat pengumpulan data berupa 30 soal tes penguasaan tata bahasa bahasa Inggris dan 10 soal tes kemampuan menulis. Sebelum dilakukan pengumpulan data, instrument telah diuji coba validitasnya dengan menggunakan korelasi point biserial sedangkan uji coba reliabiltas dengan menggunakan formula $K R 20$.

Sementara itu, analisis statistik yang digunakan adalah analisis statistic deskriptif dan statistik inferensial. Pengujian hipotesis dilakukan dengan menggunakan analisis korelasi dengan rumus product moment untuk mencari besaran hubungan antar variabel.

\section{HASIL PENELITIAN DAN PEMBAHASAN}

\section{Analisis Data}

Data hasil penelitian yang diperoleh dilapangan dianalisis secara dekriptif dengan mengetahui besaran mean, modus, median dan standar deviasi untuk masing-masing variabel penelitian. Untuk variabel penguasaan tata bahasa bahasa Inggris (X) diperoleh mean $=65,36$ median $=65,11$ modus 65,95 dan simpangan baku 9,13.

Selanjutnya data variabel kemampuan menulis narasi bahasa inggris diperoleh mean $=68,63$ median 64,97 modus 66,02 dan simpangan baku 9,12 .

\section{Uji Hipotesis}

Pengujian hipotesis merupakan analisis inferensial yang bertujuan untuk menarik kesimpulan dari sebuah penelitian. Hasil dari pengujian hipotesis 
terdiri dari penghitungan koefisien korelasi, koefisien determinasi dan koefisiensi signifikansi korelasi. Sebelum dilakukan pengujian hipotesis data sudah terlebih dahulu diuji normalitas dan linieritasnya. Hasil uji normalitas untuk variabel $\mathrm{X}$ adalah $L_{\text {hitung }}=0,1866$ dan untuk variabel $\mathrm{Y}$ adalah $\mathrm{L}_{\text {hitung }}=0,1737$ dengan $\mathrm{L}_{\text {tabel }}=$ 0,1402 . Sedangkan, hasil linieritas regreasi adalah $\mathrm{Y}=16,61+0,08 \mathrm{X}$. berdasarkan hasil perhitungan tersebut data dapat dinyatakan relative normal dan linier. Selanjutnya hasil penghitungan koefisien korelasi ( $\mathrm{r}$ ) sebesar 0,81 selanjutnya hasil uji signifikansi koefisien korelasi (t hitung) sebesar 7,445 dengan koefisien determinasi (KD) sebesar 66,43\%.

Berdasarkan hasil perhitungan koefisien korelasi diatas maka besaran nilai thitung 7,445 dibandingkan dengan $\mathrm{t}$ table dengan taraf kepercayaan 5\% dengan $\mathrm{n}=30$ sebesar 1,4. Dengan demikian dapat disimpulkan bahwa terdapat hubungan antara penguasaan tata bahasa (grammar) variabel $\mathrm{X}$, terhadap kemampuan menulis narasi bahasa Inggris variabel Y. Angka tersebut setelah dicocokan dengan koefisien korelasi termasuk kategori sangat kuat. Hal ini berarti bahwa hubungan variable $\mathrm{X}$ dengan variable $\mathrm{Y}$ sangat kuat.

Koefisien determinasi sebesar $66,43 \%$ menunjukan bahwa pada penelitian ini hubungan penguasaan tata bahasa terhadap kemampuan menulis narasi bahasa Inggris siswa sangat berpengaruh. Dengan kata lain kontribusi pengaruh penguasaan tatabahasa Inggris terhadap kemampuan menulis narasi bahasa Inggris cukup besar.

\section{SIMPULAN}

Sesuai dengan tujuan penelitian yang dilakukan oleh penulis, yaitu untuk mengetahui pengaruh tata bahasa bahasa inggris terhadap kemampuan menulis narasi bahasa Inggris siswa, maka penulis menyimpulkan berdasarkan data-data tersebut diatas penulis telah membuktikan dan mengambil kesimpulan terhadap penelitian yang penulis lakukan, yaitu adanya hubungan penguasaan tata bahasa terhadap kemampuan menulis narasi bahasa Inggris siswa, terutama dalam hal ini adalah siswa kelas XI SMK Negeri 2 Depok.

Berdasarkan kesimpulan yang telah penulis uraikan diatas, maka penulis mengemukakan beberapa saran, sebagai berikut : Dalam proses belajar mengajar, terutama dalam pembelajaran bahasa Inggris pengajar dalam hal ini adalah guru bahasa Inggris perlu memperkuat kemampuan siswa dalam menguasa tata bahasa (Grammar). Hal ini dikarenakan pentingnya posisi tata bahasa dalam penggunaan bahasa sebagai alat komunikasi. Kesalahan dalam penggunaan tata bahasa maka akan terjadi kesalahan dalam menangkap maksud yang hendak disampaikan.

\section{DAFTAR PUSTAKA}

Abdurrahman, Maman. 2011. Panduan Praktis Memahami Penelitian (Bidang Sosial-AdministrasiPendidikan). Bandung: CV. Pustaka Setia.

Alice Oshima and Ann Hogue. 2006. Wrtitting Academic English. Penerbit New York: The Longman Academic Writing Series.

Andika Pratiwi dan Gartika Rahmasari. 2012. How to Write English Correctly (Menulis Sesuai 
Kaidah Bahasa Inggris).

Penerbit Jakarta: Laskar Aksara.

Betty Schramfer Azar. 1992.

Fundamentals Of English

Grammar.Penerbit United State

of America.Regents Practice Wall.

Kyriacou Chris. 2011. Effective Teaching: Theory and Practice. United Kingdom: Nelson Thornes Ltd.

McCarthy, Michael. 1994. English Vocabulary in Use.Cambridge: Univercity Perss.

Sharon Soreseon. 1992. Webster's New World Student Writing Handbook.Penerbit
America:Funk and Wagnalls Edition.

Tarigan, Guntur Hendry. 2009. Metodologi Pengajaran Bahasa. Bandung: Angkasa.

Zainurrahman. 2011. Menulis Dari Teori Hingga Praktik (Penawar Racun Plagiarisme).Penerbit Bandung. Alfabeta.

Riyanto, Slamet. 2010. Developing Vocabulary Skills. Yogyakarta: Pustaka Pelajar.

Suryana, Agus. 2007. Vocabulary Exercise For Beginner. Jakarta: EDSA Mahkota.

Hidayat, Rachmat. 2009. Kosakata Bahasa Inggris. Yogyakarta. Pustaka Pelajar 